\title{
Mentha spicata L. grown with nitrate: Ammonium proportions in different light environments
}

Luis Cláudio Vieira Silva ${ }^{1} \mathbb{\oplus}$, Girlene Santos de Souza ${ }^{1 *}{ }^{\oplus}$, Anacleto Ranulfo dos Santos ${ }^{1} \mathbb{D}$, Joeferson Silva Santos ${ }^{1} \mathbb{D}$, Alfredo Teles de Jesus Neto ${ }^{1} \oplus$, Pedro Antônio Duarte da Hora' ${ }^{1}$, Janderson do Carmo Lima$^{2} \mathbb{0}$

\footnotetext{
1 Universidade Federal do Recôncavo da Bahia, Cruz das Almas, BA, Brasil. E-mail: luismst@yahoo.com.br; girlene@ufrb.edu.br; anacleto@ufrb.edu.br; joefersonsnts@gmail.com; alfredotelles008@outlook.com; pedroantoio99@gmail.com

${ }^{2}$ Universidade Estadual de Feira de Santana, Feira de Santana, BA, Brasil. E-mail: janderson_ufrb@yahoo.com.br
}

ABSTRACT: Mentha spicata L. is an aromatic and medicinal plant, known as mint and used in the pharmaceutical and cosmetic industry and in phytotherapy. Although the cultivation of medicinal plants is traditional, there are several questions about which practices are most appropriate in the management of these plants, especially regarding nutrition and availability of light. The objective of this work was to evaluate the growth, phytomass production and physiological aspects of $M$. spicata cultivated in proportions of nitrate $\left(\mathrm{NO}_{3}^{-}\right)$and ammonium $\left(\mathrm{NH}_{4}^{+}\right)$and light environments. The research was carried out in a greenhouse at the Universidade Federal do Recôncavo da Bahia, Cruz das Almas, BA, Brazil. The experimental design used was completely randomized, in a $5 \times 3$ factorial scheme, with five proportions of $\mathrm{NO}_{3}: \mathrm{NH}_{4}^{+}(0: 100 ; 25: 75 ; 50: 50 ; 75: 25 ; 100: 0)$ and three light environments (ChromatiNet ${ }^{\circledR}$ meshes red, black and in full sun), with seven repetitions. There was a significant interaction between the proportions of ammonium and nitrate with the light environments for most of the evaluated parameters. It is concluded that $M$. spicata plants grown under balanced proportions of nitrate and ammonium in a light environment favorably favored the initial growth and physiological indications of this species.

Key words: ionic interaction; mint; nitrogen; protected cultivation

\section{Mentha spicata L. cultivada com proporções de nitrato: Amônio em diferentes ambientes de luz}

RESUMO: Mentha spicata L. é uma planta aromática e medicinal, conhecida como hortelã e utilizada na indústria farmacêutica e de cosméticos e na fitoterapia. Embora o cultivo de plantas medicinais seja tradicional, existem várias questões sobre quais práticas são mais adequadas no manejo destas plantas, especialmente no quesito nutrição e disponibilidade de luz. O objetivo desse trabalho foi avaliar o crescimento, a produção de fitomassa e aspectos fisiológicos de $M$. spicata cultivada em proporções de nitrato $\left(\mathrm{NO}_{3}^{-}\right)$e amônio $\left(\mathrm{NH}_{4}^{+}\right)$e ambientes de luz. A pesquisa foi realizada em casa de vegetação na Universidade Federal do Recôncavo da Bahia, campus de Cruz das Almas, BA. O delineamento experimental foi inteiramente casualizado, em esquema fatorial $5 \times 3$, sendo cinco proporções de $\mathrm{NO}_{3}{ }^{-} \mathrm{NH}_{4}{ }^{+}(0: 100 ; 25: 75 ; 50: 50 ; 75: 25 ; 100: 0)$ e três ambientes de luz (malhas ChromatiNet ${ }^{\circledR}$ vermelha, preta e a pleno sol), com sete repetições. Houve interação significativa entre as proporções de amônio e nitrato com os ambientes de luz para a maioria dos parâmetros avaliados. Conclui-se que plantas de M. spicata cultivadas sob proporções balanceadas de nitrato e amônio em ambiente de luz favoreceu satisfatoriamente 0 crescimento inicial e índices fisiológicos desta espécie.

Palavras-chave: interação iônica; hortelã; nitrogênio; cultivo protegido

\footnotetext{
* Girlene Santos de Souza - E-mail: girlene@ufrb.edu.br (Corresponding author)

Associate Editor: Ana Carolina Silva Siquieroli
} 


\section{Introduction}

Among the species of aromatic, medicinal and condiment plants belonging to the Lamiaceae family, Mentha spicata L., known in several regions of Brazil as mint or mint, is a medicinal herb of economic relevance due to menthol, generally the major constituent of its essential oil, and is cultivated in several regions of the world (Bahadori et al., 2018).

Due to the active ingredients in the essential oil of $M$. spicata, the leaves are used in herbal medicine, mainly to relieve stomach problems, nasal congestion, diseases of the uterus and ovaries, muscle spasms, prevent flatulence, Alzheimer's, liver diseases, as well as having antiseptic properties (Pinha et al., 2019).

Knowing the phytotherapeutic importance of this species, it is essential to know the factors that condition its growth and development, because these do not depend only on the genetic potential of the species, but also on several factors that act together, among them: light, humidity, irrigation, soil fertility, and others.

Light is paramount for plant growth not only by providing energy for the photosynthetic process, but also by generating signals that regulate their development. Thus, modifications in light levels, to which a species is adapted, can condition different physiological responses in their biochemical, nutritional and growth characteristics, because these do not depend only on the presence, attenuation or absence of light, but also on the spectral quality of the radiation (Taiz et al., 2017).

In this sense, the use of photoconverter meshes becomes a technological innovation that can contribute to plant development, as they select spectral bands of solar radiation in order to combine physical protection with spectral light quality.

These meshes are made with high-density polyethylene film and monofilament yarns that block the passage of ultraviolet radiation and change the spectrum of the light that passes through them, reducing or increasing peak transmittance of radiation of certain wavelengths (Ginegar, 2021). In addition, they favor an increase in the percentage of diffused light, meaning greater light coverage over the plants that can contribute to changes in their physiological, morphological, and growth functions. (Souza et al., 2017).

Recent studies show that growing under $50 \%$ shade with the use of photoconverting screens can provide several modifications related to phytomass production (Lima et al., 2018; Silva et al., 2020).

Besides light another factor that directly affects the growth and development of plants is mineral nutrition, because when there is an ionic deficit or toxicity, there is a reduction in the accumulation of phytomass, especially in the assimilation and incorporation of nitrogen, because this nutrient is an integral part of several biological macromolecules and secondary metabolites, and its absence limits the survival of the plant (Peixoto et al., 2020).
Nitrogen, considered as one of the most critical nutrients for agricultural productivity, is taken up by the root system mainly in the ionic forms of nitrate $\left(\mathrm{NO}_{3}{ }^{-}\right)$and ammonium $\left(\mathrm{NH}_{4}^{+}\right)$, with the first form predominating, because in the soil the concentration of ammonium ion is low, resulting from rapid oxidation to $\mathrm{NO}_{3}^{-}$by nitrifying organisms (MartínezAndújar et al., 2013).

It is worth noting that the relative uptake rates of $\mathrm{NO}_{3}$ and $\mathrm{NH}_{4}^{+}$by higher plants are influenced by several factors, such as the species under study, the proportion of these ions in the growth solution, $\mathrm{pH}$, temperature, light intensity, carbohydrate concentration in the roots, and others.

In most cultivated plants, the exclusive uptake of $\mathrm{NO}_{3}$ - or $\mathrm{NH}_{4}{ }^{+}$ions negatively affects cellular metabolism, because the former to be absorbed involves high energy cost and specific enzymes to be reduced into $\mathrm{NH}_{4}^{+}$. Already this ion does not require energy expenditure, however, high concentration causes toxicity at the cellular level affecting the physiology and morphology of most plants (Taiz et al., 2017).

Several researches refer to the independent action of abiotic factors on crop production, however, studies are needed to fully understand the mutual influence of biological and environmental factors on plant growth and development.

In this context, the research aimed to evaluate the vegetative growth of $M$. spicata L. grown under different proportions of nitrate and ammonium in different light environments.

\section{Materials and Methods}

The research was conducted in the period from September 2019 to January 2020, in a vegetation house, located at the Universidade Federal do Recôncavo da Bahia (UFRB), in the municipality of Cruz das Almas, BA, Brazil, located $140 \mathrm{~km}$ from Salvador, BA, Brazil, whose geographic coordinates are $12^{\circ} 40^{\prime} 12^{\prime \prime} \mathrm{S}, 39^{\circ} 06^{\prime} 07^{\prime \prime} \mathrm{W}$, with an altitude of $220 \mathrm{~m}$. The region climate, according to Köppen and Geiger, is of type Af, tropical climate, with an average temperature of $23.0^{\circ} \mathrm{C}$ and average annual rainfall of $1,136 \mathrm{~mm}$.

The seedlings of $M$. spicata were vegetatively propagated by cuttings in a nursery with shade of $50 \%$ of transmittance in the photosynthetically active region, belonging to the Center for Agrarian, Environmental and Biological Sciences of UFRB, obtained from mother plants acquired from a home garden located in the municipality of Cruz das Almas, BA, Brazil. The cuttings were rooted in polyethylene trays consisting of 200 cells, containing as substrate washed sand and bovine manure in a 3:1 ratio, respectively.

After 30 days of rooting, the seedlings were transplanted. For homogenization purposes, plants with a root length of 8.0 $\mathrm{cm}$ and height of $15 \mathrm{~cm}$ were standardized.

The seedlings were placed in polypropylene pots with $3.0 \mathrm{dm}^{3}$ capacity, filled with washed sand and vermiculite in a 2:1 ratio, respectively. The water replacement, in each experimental unit, was done daily, with $200 \mathrm{~mL}$ of distilled water in order to maintain soil moisture for plant growth. 
The experimental design used was an entirely randomized $5 \times 3$ factorial scheme, with five nitrate and ammonium ratios $(100: 0 ; 75: 25 ; 50: 50 ; 25: 75 ; 0: 100)$ and three light environments, obtained with the use of ChromatiNET red, black (Polysack Plastic Industries ${ }^{\circledR}$ ) and a full sun treatment used as a witness. Each treatment contained seven repetitions with one plant per pot, for a total of 105 experimental units.

Black ChromatiNet meshes were used for the shading effect, and red meshes were used because they have a higher transmittance at wavelengths above $590 \mathrm{~nm}$ (red) and a lower peak around $400 \mathrm{~nm}$ (violet), reducing blue, green and yellow waves.

The $\mathrm{NO}_{3}^{-}: \mathrm{NH}_{4}^{+}$concentrations are shown in Table 1 , and the treatments were established based on the nitrogen (N) concentration used by the Hoagland \& Arnon (1950) solution. The nutrient solution was composed of macro and micronutrients in $\mathrm{mg} \mathrm{L}^{-1}$ concentration: $\mathrm{N}=210, \mathrm{P}=31, \mathrm{~K}=234$, $\mathrm{Ca}=200, \mathrm{Mg}=48$, and $\mathrm{S}=64, \mathrm{pH}=5.6( \pm 1)$. The distribution of treatments was started eight days after transplanting and acclimatization of the seedlings.

The following growth parameters were evaluated 90 days after the beginning of the treatment distribution: number of leaves per plant (NL), determined by direct leaf count on each plant; root system volume (RV), determined by displacing water contained in a $2,000 \mathrm{~mL}$ graduated cylinder with subsequent submersion of the dry mass of the root system; chlorophyll index $a, b$, total $(a+b)$ and $a / b$ ratio, using an electronic meter $\mathrm{FCl}$ (Folker Chlorophyll Index) between the leaf lamina of the middle third of the branch, between the hours of 06:00 a.m. and 08:00 a.m.

M. spicata plants were collected and partitioned into root, stem, and leaf, individually wrapped in previously identified Kraft paper bags, and dehydrated in a forced air circulation oven at $45 \pm 2{ }^{\circ} \mathrm{C}$ until they reached constant mass. The dry matter masses of the root system (RDM), stem (SDM), and leaf (LDM) were measured and recorded using a precision analytical balance to three decimal places. The sum of these latter phytomasses gives the dry matter mass of the aboveground part (SHDM) and of the plant (DMP), from the combined SHDM and RDM.

Table 1. Volume $(\mathrm{mL})$ of the stock solutions to form $1 \mathrm{~L}$ of modified nutrient solution, using ratios of nitrate and ammonium $\left(\mathrm{NO}_{3}^{-}: \mathrm{NH}_{4}^{+}\right)$as per the respective treatments.

\begin{tabular}{lccccc}
\hline \multirow{2}{*}{$\begin{array}{c}\text { Stock solution } \\
(1 \mathrm{M})\end{array}$} & \multicolumn{5}{c}{ Ratios $\left(\mathrm{NO}_{3}{ }^{-}: \mathrm{NH}_{4}{ }^{+}\right)$} \\
\cline { 2 - 6 } & $\mathbf{1 0 0 : 0}$ & $\mathbf{7 5 : 2 5}$ & $\mathbf{5 0 : 5 0}$ & $\mathbf{2 5 : 7 5}$ & $\mathbf{0 : 1 0 0}$ \\
\cline { 2 - 6 }$\left(\mathbf{m m o l ~ L}^{-1}\right)$ \\
\hline $\mathrm{KH}_{2} \mathrm{PO}_{4}$ & 1.0 & 1.0 & 1.0 & 1.0 & 1.0 \\
$\mathrm{NH}_{4} \mathrm{Cl}$ & - & 3.7 & 7.5 & 11.2 & 15 \\
$\mathrm{KCl}$ & - & 3.8 & - & 1.2 & 5.0 \\
$\mathrm{CaCl}_{2}$ & - & - & 3.0 & 5.0 & 5.0 \\
$\mathrm{MgSO}_{4}$ & 2.0 & 2.0 & 2.0 & 2.0 & 2.0 \\
$\mathrm{KNO}_{3}$ & 5.0 & 1.2 & 5.0 & 3.7 & - \\
\hline $\mathrm{Ca}\left(\mathrm{NO}_{3}\right)_{2} \cdot 4 \mathrm{H}_{2} \mathrm{O}$ & 5.0 & 5.0 & 2.0 & - & - \\
Iron - EDTA* & 1.0 & 1.0 & 1.0 & 1.0 & 1.0 \\
\hline Micronutrients** & 1.0 & 1.0 & 1.0 & 1.0 & 1.0 \\
\hline
\end{tabular}

** Micronutrient solutions $\left(\mathrm{g} \mathrm{L}^{-1}\right): \mathrm{H}_{3} \mathrm{BO}_{3}=2.86 ; \mathrm{MnCl}_{2} 4 \mathrm{H}_{2} \mathrm{O}=1.81 ; \mathrm{ZnCl}_{2}=0.10 ; \mathrm{CuCl}_{2}=$ $0.04 ; \mathrm{H}_{2} \mathrm{MoO}_{4} \mathrm{H}_{2} \mathrm{O}=0.02$. ${ }^{*}$ Iron solution-EDTA: $26.1 \mathrm{~g}$ of EDTA disodium was dissolved in $286 \mathrm{~mL}$ of $\mathrm{NaOH} 1 \mathrm{~mol} \mathrm{~L}^{-1}+24.9 \mathrm{~g}$ of $\mathrm{FeSO}_{4} \cdot 7 \mathrm{H}_{2} \mathrm{O}$ and aerated overnight.
The leaf area (LA) was determined in $\mathrm{cm}^{2}$ and was obtained using a perforator with known diameter (6 $\mathrm{mm})$, being collected 10 leaf discs in each plant in randomly chosen leaves avoiding the central vein regions (Peixoto et al., 2011).

The specific leaf area (SLA) was determined by the ratio LA/LDM, expressed in $\mathrm{cm}^{2} \mathrm{~g}^{-1}$, being a variable that includes the surface, morphological component, and the phytomass, anatomical component, related to the internal composition formed by the number and/or size of cells of the leaf mesophyll. The leaf mass ratio (LMR) determined by the expression LDM/ DMP, expresses the fraction of dry matter not exported.

The experimental data were submitted to statistical analysis of variance and, according to the significance level by $\mathrm{F}$ test, for $\mathrm{NO}_{3}^{-}: \mathrm{NH}_{4}^{+}$ratios, light environments and their interaction, the mean test was performed (Tukey 5\%), using the statistical program SISVAR ${ }^{\circledR} 5.3$ (Ferreira, 2008).

\section{Results and Discussion}

It was verified from the summary of the analysis of variance (Table 2), that there was no significant effect for $\mathrm{NO}_{3}^{-}: \mathrm{NH}_{4}^{+}$ and light environment interactions on the chlorophyll $b$ index, chlorophyll a/b ratio, and leaf area. In the other parameters evaluated, there was a significant effect of the mutual influence of these factors ( $p \leq 0.05$ ), thus demonstrating that the species $M$. spicata responds to the different relationships between $\mathrm{NO}_{3}{ }^{-}$and $\mathrm{NH}_{4}{ }^{+}$ions in different light environments.

Plants of $M$. spicata grown in shaded environments showed higher leaf number (NL) compared to those grown in full sun (Table 3). This performance was also influenced by ammonium and nitrate concentrations, observing significant effect for the 100:0; 25:75 and 0:100 $\mathrm{NO}_{3}^{-}: \mathrm{NH}_{4}^{+}$ratios under the red mesh and 100:0; 50:50 and 0:100 $\mathrm{NO}_{3}^{-}: \mathrm{NH}_{4}^{+}$under the black mesh. The red photoconverting screen, associated with the 25:75 $\mathrm{NO}_{3}^{-}: \mathrm{NH}_{4}^{+}$ratio, favored an increase in $\mathrm{NL}$ of approximately $38.89 \%$ compared to the full sun treatment using the same ratio, showing the effect of this treatment on the main commercial factor of this species, which is precisely the leaves.

This effect is attributed to the adaptation of the species to the environment, as there is a need for low light irradiances to overcome the light compensation point, favoring the growth of the plant. Therefore, plants exposed to high light irradiances and high temperatures tend to show lower $\mathrm{NL}$ due to photorespiration, a competitive inhibition with photosynthesis that consumes ATP as oxygen and releases carbon dioxide, thus making it a costly process for plants (Taiz et al., 2017).

Sousa et al. (2010) found that the number of leaves of the eggplant crop was significantly affected by $\mathrm{NO}_{3}^{-}: \mathrm{NH}_{4}^{+}$ratios, with an increasing response being observed up to the $75: 25$ ratio. The lowest values were obtained in plants supplied with only one of the $\mathrm{N}$ forms, mainly in the ammonium form. While Cruz et al. (2006) when studying the effect of nitrate and ammonium on growth and $\mathrm{N}$ use efficiency in cassava, observed that treatments consisting exclusively of nitrate or 
Table 2. Summary of analysis of variance for leaf number (LN), chlorophyll a (CLA), chlorophyll b (CLB), total chlorophyll (TCL), chlorophyll a/b ratio (CLA/B), leaf dry matter masses (LDM), stem (SDM), root (RDM), above ground (SHDM), plant (DMP), root volume (RV), leaf area (LA), specific leaf area (SLA) and leaf mass ratio (LMR) of $M$. spicata L. grown under proportions of nitrate and ammonium in different light environments, Cruz das Almas, BA, Brazil.

\begin{tabular}{|c|c|c|c|c|c|c|c|}
\hline \multirow{2}{*}{$\begin{array}{c}\text { Source } \\
\text { of variation }\end{array}$} & \multicolumn{7}{|c|}{ Mean square } \\
\hline & NL & CLA & CLB & CLT & CLA/B & LDM & SDM \\
\hline $\mathrm{NO}_{3}^{-}: \mathrm{NH}_{4}^{+}(\mathrm{N})$ & $19160.40^{\text {ns }}$ & $11.01^{\mathrm{ns}}$ & $16.36^{\mathrm{ns}}$ & $47.20^{\mathrm{ns}}$ & $0.30^{\mathrm{ns}}$ & $11.09^{n s}$ & $14.11^{\mathrm{ns}}$ \\
\hline Environment (A) & $56649.60^{\mathrm{ns}}$ & $13.08^{\mathrm{ns}}$ & $1.12^{\mathrm{ns}}$ & $14.66^{\mathrm{ns}}$ & $0.02^{\mathrm{ns}}$ & $13.57^{\mathrm{ns}}$ & $33.62^{\mathrm{ns}}$ \\
\hline CV (\%) & 15.23 & 7.70 & 11.45 & 9.85 & 5.15 & 16.96 & 10.90 \\
\hline Source & \multicolumn{7}{|c|}{ Mean square } \\
\hline Environment (A) & $95.24^{n s}$ & $89.86^{\text {ns }}$ & $112.12^{\mathrm{ns}}$ & $46.79^{n s}$ & $58802.1^{\mathrm{ns}}$ & $993.59 \mathrm{~ns}$ & $0.018^{n s}$ \\
\hline$N^{*} A$ & $25.53^{*}$ & 13.99* & $71.37^{*}$ & $6.67^{*}$ & $1830.5^{\mathrm{ns}}$ & $62.09 *$ & $0.002 *$ \\
\hline CV (\%) & 21.99 & 10.08 & 13.52 & 13.45 & 173.6 & 8.13 & 10.93 \\
\hline
\end{tabular}

* - Significant at $5 \%$ level by F-test; ${ }^{\text {ns }}$ - non-significant.

Table 3. Interaction between the proportions of nitrate and ammonium and light environments for the variables leaf number $(\mathrm{NL})$, specific leaf area (SLA), chlorophyll a (CLA) and total chlorophyll (CLT) in plants of M. spicata L. Cruz das Almas, BA, Brazil.

\begin{tabular}{|c|c|c|c|c|c|c|}
\hline \multirow{3}{*}{$\mathrm{NO}_{3}^{-}: \mathrm{NH}_{4}^{+}$} & \multicolumn{3}{|c|}{ NL } & \multicolumn{3}{|c|}{$\operatorname{SLA}\left(\mathrm{cm}^{2} \mathrm{~g}^{-1}\right)$} \\
\hline & \multicolumn{6}{|c|}{ Light environment } \\
\hline & Full Sun & Mesh Black & Mesh Red & Full Sun & Mesh Black & Mesh Red \\
\hline $100: 0$ & $260.16 \mathrm{bB}$ & $330.00 \mathrm{abA}$ & $363.00 \mathrm{abA}$ & $16.72 \mathrm{cC}$ & $26.28 \mathrm{abB}$ & 30.76 aA \\
\hline $75: 25$ & 333.42 bcA & $308.00 \mathrm{bA}$ & $331.85 \mathrm{bA}$ & $15.347 \mathrm{cB}$ & $27.48 \mathrm{abA}$ & $28.41 \mathrm{aA}$ \\
\hline $50: 50$ & 398.57 aA & $400.42 \mathrm{aA}$ & $339.57 \mathrm{bA}$ & $17.30 \mathrm{bcB}$ & 28.93 aA & $29.07 \mathrm{aA}$ \\
\hline $25: 75$ & $262.71 \mathrm{bC}$ & $344.42 \mathrm{abB}$ & 429.85 aA & 19.94 bC & $25.16 \mathrm{bB}$ & 30.85 aA \\
\hline $0: 100$ & $181.85 \mathrm{cB}$ & $368.14 \mathrm{abA}$ & $362.00 \mathrm{abA}$ & 26.85 aA & $28.93 \mathrm{aA}$ & $28.69 \mathrm{aA}$ \\
\hline \multirow{3}{*}{$\mathrm{NO}_{3}: \mathrm{NH}_{4}^{+}$} & & CLA & & & CLT & \\
\hline & \multicolumn{6}{|c|}{ Light environment } \\
\hline & Full Sun & Mesh Black & Mesh Red & Full Sun & Mesh Black & Mesh Red \\
\hline 100:0 & 33.15 aA & $29.49 \mathrm{aB}$ & $28.36 \mathrm{aB}$ & 44.35 aA & $38.19 \mathrm{aAB}$ & $36.65 \mathrm{aB}$ \\
\hline $75: 25$ & 31.14 aA & 30.87 aA & $28.34 \mathrm{aA}$ & 41.42 baA & 40.47 aA & 40.56 aA \\
\hline $50: 50$ & 30.74 aA & $29.70 \mathrm{aA}$ & 29.32 aA & 40.23 baA & 38.77 aA & 38.16 aA \\
\hline $25: 75$ & $27.20 \mathrm{bB}$ & 30.82 aA & $30.03 \mathrm{aAB}$ & $35.03 \mathrm{bcA}$ & $40.47 \mathrm{aA}$ & 38.93 aA \\
\hline $0: 100$ & $24.97 \mathrm{bB}$ & 30.65 aA & 30.04 aA & $31.79 \mathrm{cB}$ & 40.16 aA & $38.71 \mathrm{aA}$ \\
\hline
\end{tabular}

* Lower case letters for comparison between columns and capital letters in equal rows do not differ, by Tukey's test at $5 \%$ probability.

ammonium provided lower leaf numbers. The results observed by these authors agree with those found in this study, where it was found that the exclusive $\mathrm{N}$ supply interfered with the growth of M. spicata plants.

In relation to the specific leaf area (SLA), there was a significant effect for the interaction in plants grown in full sun in the ratio 0:100 $\mathrm{NO}_{3}: \mathrm{NH}_{4}^{+}$, as well as for those grown under black mesh in the ratios 75:25; 50:50; 0:100 $\mathrm{NO}_{3}{ }_{3}: \mathrm{NH}_{4}{ }^{+}$and in red mesh with all the ratios studied (Table 3 ). For Peixoto et al. (2020), the increases in SLA are relevant because they point to morphological adaptations that allow the plant to form a more efficient leaf area.

In the red mesh environment it was highlighted that in the $25: 75 \mathrm{NO}_{3}^{-}: \mathrm{NH}_{4}{ }^{+}$ratio there was an increase of $12.96 \%$ compared to the average achieved in the 0:100 treatment in the no mesh environment (Table 3). Corroborating these results, Matos et al. (2015) found isolated effect of ammonium on basil plants under decreased NL and SLA.

Exclusive ammonium supply limits cell division and leaf expansion implying lower photosynthetic capacity of the plant, thus causing lower SLA (Liu et al., 2018). According to Teixeira et al. (2013), plants grown in low irradiance conditions invest a greater proportion of photoassimilates in increasing leaf area, consequently there will be greater SLA causing greater interception of incident light, increasing the photosynthetic efficiency of the plant.

Regarding the chlorophyll-a index (CLA), a significant interaction was observed for plants grown in full sun at the ratios 100:0; 75:25 and 50:50 $\mathrm{NO}_{3}: \mathrm{NH}_{4}{ }^{+}$, as well as for those grown under black and red mesh in all ratios studied except for $100: 0 \mathrm{NO}_{3}^{-}: \mathrm{NH}_{4}^{+}$. There is a $14.5 \%$ increase in the $100: 0$ $\mathrm{NO}_{3}^{-}: \mathrm{NH}_{4}^{+}$ratio in the mesh-free environment, compared to the lowest ratio from the $75: 25 \mathrm{NO}_{3}: \mathrm{NH}_{4}^{+}$ratio under the red mesh (Table 3).

With reference to the total chlorophyll index (CLT), significant interaction was observed between all light environments and nitrate and ammonium ratios, except for 25:75 and 0:100 $\mathrm{NO}_{3}^{-}: \mathrm{NH}_{4}{ }^{+}$in full sun and 100:0 $\mathrm{NO}_{3}^{-}: \mathrm{NH}_{4}^{+}$ under red mesh (Table 3). It was observed that the highest significant mean was achieved in plants grown at the 100:0 
$\mathrm{NO}_{3}^{-}: \mathrm{NH}_{4}^{+}$ratio in an unshaded environment. Similar results were observed in Butia capitata (Mart.) where the authors concluded that the use of photoconverting meshes does not influence the physiological characteristics of this species (Costa et al., 2018).

It is pointed out that the increase in chlorophyll is due to the greater uptake and incorporation of $\mathrm{N}$ in the nitrate form, and thus it is inferred that the supply of $\mathrm{N}$ in the ammonium form may have impaired the assimilation of this nutrient thus decreasing the chlorophyll content. Contradictory results were found by Yang et al. (2020), where these authors observed that CLA contents and CLA/B ratio were higher at the 75:25 $\mathrm{NH}_{4}^{+}: \mathrm{NO}_{3}^{-}$ratio in Brassica rapa plants.

Regarding leaf dry matter mass yield (LDM), significant interactions were seen in plants grown in full sun at the 100:0; 75:25; 50:50 $\mathrm{NO}_{3}-\mathrm{NH}_{4}{ }^{+}$ratios. In relation to the shaded environment with the black and red meshes the interaction occurred at the ratios 75:25; $50: 50 ; 25: 75$ and $0: 100 \mathrm{NO}_{3}^{-}: \mathrm{NH}_{4}^{+}$ and 100:0; 25:75; 0:100 $\mathrm{NO}_{3}^{-}: \mathrm{NH}_{4}^{+}$, respectively (Table 4).

It is noteworthy that plants grown in a black mesh environment, at a 75:25 $\mathrm{NO}_{3}^{-}: \mathrm{NH}_{4}^{+}$ratio, showed higher LDM production, obtaining a higher percentage of 13.97 and $29.30 \%$ compared to the yield of those grown in full sun and under red mesh respectively, both grown at 100:0 $\mathrm{NO}_{3}^{-}: \mathrm{NH}_{4}{ }^{+}$ concentration (Table 4).

The photosynthetic efficiency under conditions of low light availability is a function of phenotypic plasticity, being reflected in the larger leaf area with less thickness, resulting in better use of incident radiation around the mesophyll (Amarante et al., 2009). The presence of ammonium ion, at a proportion of $25 \%$ of the solution, favored increased production of LDM, showing the importance of adequate $\mathrm{NO}_{3}$ and $\mathrm{NH}_{4}{ }^{+}$ion balance in the nutrient solution as a consequence of efficient nitrogen use by the plant.

Plants of $M$. spicata grown in full sun and with the nutrient solution containing nitrate and ammonium in the proportions 100:0 and 75:25 showed an increase in their performance for stem dry matter mass (SDM) as a function of the significant interaction. The same effect was also observed between the black mesh and all $\mathrm{NO}_{3}^{-}: \mathrm{NH}_{4}^{+}$ratios except for the 0:100 ratio, and between the red mesh with 100:0 and 0:100 of $\mathrm{NO}_{3}: \mathrm{NH}_{4}^{+}$. Balancing the $\mathrm{NO}_{3}^{-}: \mathrm{NH}_{4}^{+}$ions in the $75: 25$ ratio promoted the greatest increase in SDM in plants grown in full sun and black mesh (Table 4).

The aboveground dry matter mass (SHDM) is an important parameter, as it indicates the investment of photo-assimilates in leaves and stems. Significant interactions were found between plants grown in full sun and the 100:0; 75:25 $\mathrm{NO}_{3}$ $: \mathrm{NH}_{4}^{+}$ratios, as well as between those grown under the black mesh and the $75: 25 ; 50: 50 ; 25: 75 \mathrm{NO}_{3}{ }^{-}: \mathrm{NH}_{4}{ }^{+}$ratios and under the red mesh at the $0: 100 \mathrm{NO}_{3}^{-}: \mathrm{NH}_{4}{ }^{+}$ratio.

The highest increment of SHDM was observed in black mesh shaded environment in interaction with 75:25 $\mathrm{NO}_{3}^{-}: \mathrm{NH}_{4}^{+}$ ratio, with an increase of 9.6 and $29.74 \%$ when compared to

Table 4. Interaction between nitrate-ammonium ratios and light environments for the variables leaf dry matter mass (LDM), stem dry matter mass (SDM), aboveground dry matter mass (SHDM), root dry matter mass (RDM), plant dry matter mass (DMP) and root volume (RV) in M. spicata L. plants. Cruz das Almas, BA, Brazil.

\begin{tabular}{|c|c|c|c|c|c|c|}
\hline \multirow{4}{*}{$\mathrm{NO}_{3}^{-}: \mathrm{NH}_{4}^{+}$} & \multicolumn{3}{|c|}{ LDM } & \multicolumn{3}{|c|}{ SDM } \\
\hline & \multicolumn{6}{|c|}{ (g planta-1) } \\
\hline & \multicolumn{6}{|c|}{ Light environment } \\
\hline & Full Sun & Mesh Black & Mesh Red & Full Sun & Mesh Black & Mesh Red \\
\hline $75: 25$ & $6.34 \mathrm{aAB}$ & $7.44 \mathrm{aA}$ & $5.39 \mathrm{aB}$ & $8.98 \mathrm{aA}$ & $9.54 \mathrm{aA}$ & $7.76 \mathrm{aB}$ \\
\hline $50: 50$ & $5.60 \mathrm{abAB}$ & $6.68 \mathrm{abA}$ & $5.40 \mathrm{aB}$ & $7.15 \mathrm{bcB}$ & $9.35 \mathrm{aA}$ & $7.74 \mathrm{aB}$ \\
\hline \multirow{4}{*}{$\mathrm{NO}_{3}{ }^{-}: \mathrm{NH}_{4}{ }^{+}$} & & SHDM & & & RDM & \\
\hline & \multicolumn{6}{|c|}{ (g planta-1) $^{-1}$} \\
\hline & \multicolumn{6}{|c|}{ Light environment } \\
\hline & Full Sun & Mesh Black & Mesh Red & Full Sun & Mesh Black & Mesh Red \\
\hline $100: 0$ & $14.70 \mathrm{abA}$ & $14.85 \mathrm{bcA}$ & $12.78 \mathrm{aB}$ & $12.52 \mathrm{aA}$ & $7.26 \mathrm{aB}$ & $6.50 \mathrm{aA}$ \\
\hline \multirow{3}{*}{$\mathrm{NO}_{3}^{-}: \mathrm{NH}_{4}^{+}$} & & MP (g planta- & & & $\operatorname{RV}\left(\mathrm{cm}^{3}\right)$ & \\
\hline & \multicolumn{6}{|c|}{ Light environment } \\
\hline & Full Sun & Mesh Black & Mesh Red & Full Sun & Mesh Black & Mesh Red \\
\hline $100: 0$ & $27.22 \mathrm{aA}$ & $22.12 \mathrm{aB}$ & $19.28 \mathrm{aB}$ & $12.33 \mathrm{aA}$ & $9.14 \mathrm{bB}$ & $8.28 \mathrm{aB}$ \\
\hline $75: 25$ & 29.04 aA & $24.07 \mathrm{aB}$ & $19.92 \mathrm{aC}$ & $10.71 \mathrm{abA}$ & $9.42 \mathrm{bAB}$ & $8.42 \mathrm{aB}$ \\
\hline $50: 50$ & $20.57 \mathrm{bAB}$ & $22.81 \mathrm{aA}$ & $18.47 \mathrm{abB}$ & $10.14 \mathrm{bA}$ & 8.42 bB & $6.57 \mathrm{bC}$ \\
\hline $25: 75$ & $16.97 \mathrm{bB}$ & $21.31 \mathrm{abA}$ & $17.56 \mathrm{abB}$ & 7.57cC & $8.00 \mathrm{bA}$ & $5.85 \mathrm{bB}$ \\
\hline $0: 100$ & $11.36 \mathrm{cB}$ & $17.97 \mathrm{bA}$ & $14.59 \mathrm{bAB}$ & $5.42 \mathrm{dAB}$ & $5.57 \mathrm{aA}$ & $4.0 \mathrm{cB}$ \\
\hline
\end{tabular}

* Lower case letters for comparison between columns and capital letters in equal rows do not differ, by Tukey's test at $5 \%$ probability. 
no mesh and red mesh environment, respectively. This result can be attributed to the level of light intensity, phenological stage of the plant, increase in leaf area and availability of nutrients, especially nitrogen (Alves et al., 2018; Lima et al., 2018; Chen et al., 2019).

As for the results of root dry matter mass (RDM), significant interaction was observed between the full sun environment and the 100:0 and 75:25 $\mathrm{NO}_{3}^{-}: \mathrm{NH}_{4}{ }^{+}$ratios, under the black mesh associated with the $50: 50 ; 25: 75 \mathrm{NO}_{3}{ }^{-}: \mathrm{NH}_{4}{ }^{+}$ratios and under the red mesh with the 100:0 and 25:75 $\mathrm{NO}_{3}^{-}: \mathrm{NH}_{4}^{+}$ratios (Table 4).

Plants grown in full sun and at a $75: 25 \mathrm{NO}_{3}^{-}: \mathrm{NH}_{4}^{+}$ratio showed higher root dry matter mass yields compared to those grown under red and black mesh (Table 4). This effect is related to the high light intensity, since in shaded environments there is a low photosynthetic rate in relation to plants grown in environments with greater light availability, consequently there will be little translocation of photo-assimilates to the root system.

Regarding the plant dry matter mass (DMP) of $M$. spicata grown in full sun and at the 100:0 and 75:25 $\mathrm{NO}_{3}^{-}: \mathrm{NH}_{4}^{+}$ratios, significant effects were observed, as well as in the other interactions with the black mesh and the 50:50 and 25:75 $\mathrm{NO}_{3}$ $: \mathrm{NH}_{4}{ }^{+}$ratios. The highest yield was observed in the 75:25 $\mathrm{NO}_{3}^{-}$ $: \mathrm{NH}_{4}^{+}$ratio in full sun, with a percentage of $21.45 \%$ compared to the average of those grown under black mesh in the 50:50 $\mathrm{NO}_{3}^{-}: \mathrm{NH}_{4}^{+}$ratio.

This effect was attributed to the high light intensity in full sun, providing greater phytomass production and nutrient assimilation in the organs. These results contradict the observations of Silva et al. (2020) that there was a beneficial effect of mesh shading on the phytomass production of salvia plants compared to plants grown in full sun.

The results found for root volume (RV) followed the same performance as those presented for MSR, highlighting significant interactions for the full sun environment and the 100:0; 75:25 $\mathrm{NO}_{3}^{-}: \mathrm{NH}_{4}^{+}$ratios and that under the black mesh with the 0:100 $\mathrm{NO}_{3}^{-}: \mathrm{NH}_{4}^{+}$ratio (Table 4).

It can be seen in the results observed that the $M$. spicata plants presented a preference for nitric $\mathrm{N}$ over ammoniacal $\mathrm{N}$ for most of the parameters evaluated. This behavior may be due to the fact that $\mathrm{NH}_{4}{ }^{+}$absorption promotes the acidification of the external medium and, consequently, limits the absorption of cationic ions in the substrate solution, such as $\mathrm{Ca}^{+2}, \mathrm{Mg}^{+2}$, and $\mathrm{K}^{+}$, indispensable for plant growth and development. Moreover, in many plant species, when ammonium is the only nitrogen source available in the medium, photosynthetic activity is reduced (Guo et al., 2012; Barreto et al., 2018).

The results found for the leaf mass ratio (LMR) variable revealed that there was a significant interaction between the full sun environment and the 100:0; 50:50 $\mathrm{NO}_{3}^{-}: \mathrm{NH}_{4}^{+}$ratios, in the black mesh environment in all ratios except 100:0 $\mathrm{NO}_{3}$ $: \mathrm{NH}_{4}{ }^{+}$and under the red mesh in the 50:50; 25:75 and 0:100 $\mathrm{NO}_{3}^{-}: \mathrm{NH}_{4}^{+}$ratios (Table 5 ).

Plants grown in a red mesh environment at a 0:100 $\mathrm{NO}_{3}^{-}$ $: \mathrm{NH}_{4}{ }^{+}$ratio showed the highest RMF, being $18.20 \%$ higher than the average achieved in plants grown in full sun at a 50:50 $\mathrm{NO}_{3}^{-}: \mathrm{NH}_{4}^{+}$ratio (Table 5).
Table 5. Interaction between nitrate-ammonium ratios and light environments for the leaf mass ratio (LMR) variables in plants of M. spicata L. grown in different ammonium nitrate ratios and light environments, Cruz das Almas, BA, Brazil.

\begin{tabular}{cccc}
\hline & \multicolumn{3}{c}{ LMR $\left(\mathrm{cm}^{2} \mathbf{~ g}^{-1}\right)$} \\
\cline { 2 - 4 } $\mathrm{NO}_{3}{ }^{-}: \mathrm{NH}_{4}{ }^{+}$ & \multicolumn{3}{c}{ Light environment } \\
\cline { 2 - 4 } & Full Sun & Mesh Black & Mesh Red \\
\hline $100: 0$ & $0.23 \mathrm{abA}$ & $0.26 \mathrm{bA}$ & $0.27 \mathrm{bB}$ \\
$75: 25$ & $0.22 \mathrm{bB}$ & $0.30 \mathrm{aA}$ & $0.27 \mathrm{bA}$ \\
$50: 50$ & $0.27 \mathrm{aA}$ & $0.29 \mathrm{abA}$ & $0.29 \mathrm{abA}$ \\
$25: 75$ & $0.25 \mathrm{abB}$ & $0.28 \mathrm{abAB}$ & $0.31 \mathrm{abA}$ \\
$0: 100$ & $0.26 \mathrm{abB}$ & $0.29 \mathrm{abAB}$ & $0.33 \mathrm{aA}$ \\
\hline
\end{tabular}

Lower case letters for comparison between columns and capital letters in equal rows do not differ, by Tukey's test at $5 \%$ probability.

This result is highlighted with great relevance, because in medicinal plants, the leaves are the main organs marketed due to the presence of bioactives. Thus, high LMR becomes necessary, as it is indicative of a greater allocation of dry matter to the leaves than to the roots.

The spectral quality of the red mesh favored a greater differential distribution of photosynthetic products between leaf growth and other plant parts when compared to those grown in an environment without mesh. According to Lima et al. (2018), decline in LMR occurs as the plant grows due to self-shading causing reduction in photosynthetically active LA.

\section{Conclusions}

Plants of $M$. spicata grown exclusively on $\mathrm{N}^{-\mathrm{NH}_{4}+}$ show growth limitations.

The interaction between black mesh and the 75:25 $\mathrm{NO}_{3}: \mathrm{NH}_{4}^{+}$ratio promote significant increases in plant dry phytomass.

Shading with red and black mesh, positively influence the physiological parameters for $M$. spicata plants.

\section{Acknowledgments}

To the Conselho Nacional de Desenvolvimento Científico e Tecnológico (CNPq) for granting the scholarship to the first author.

\section{Compliance with Ethical Standards}

Author contributions: Conceptualization: LCVS, GSS, ARS; Data curation: LCVS, JSS, PADH, ATJN; Formal analysis: GSS, ARS, JCL; Funding acquisition: LCVS, ARS; Investigation: LCVS, PADH, ATJN, JSS, JCL; Methodology: ARS, LCVS, GSS; Project administration: GSS, ARS, LCVS, JSS, ATJN; Resources: GSS, ARS, JCL; Supervision: GSS, ARS, JCL; Validation: GSS, LCVS, JCL, Silva, JSS, PADH, ATJN; Visualization: GSS, LCVS, JCL; Writing - original draft: LCVS, JSS, ATJN, PADH; Writing - review \& editing: GSS, ARS, JCL.

Conflict of interest: The authors declare no conflict of interest.

Funding: Conselho Nacional de Desenvolvimento Científico e Tecnológico (CNPq). 


\section{Literature Cited}

Alves, A.C.; Jesus, F.N.; Alves, P.B.; Santos, H.V.; Souza, G.S.; Santos, A.R. Biomass production and essential oil of lemon balm cultivated under colored screens and nitrogen. Horticultura Brasileira, v.36, n.1, p.94-99, 2018. https://doi.org//10.1590/ s0102-053620180116.

Amarante, C.V.T.; Steffens, C.A.; Miqueloto, A.; Zanardi, O.Z; Santos H.P. Disponibilidade de luz em macieiras 'Fuji' cobertas com telas antigranizo e seus efeitos sobre a fotossíntese, o rendimento e a qualidade dos frutos. Revista Brasileira de Fruticultura, v.31, n.3, p.664-670, 2009. https://doi.org/10.1590/S010029452009000300007.

Bahadori, M.B; Zengin, G.; Bahadori, S.; Dinparast, L.; Movahhedin, $\mathrm{N}$. Phenolic composition and functional properties of wild mint (Mentha longifolia var. calliantha (Stapf) Briq.). Internation Journal of Food Properties, v.21, n.1, p.183-193, 2018. https:// doi.org/10.1080/10942912.2018.1440238.

Barreto, R.F.; Cruz, F.J.R.; Gaion, L.A; Prado, R. M.; Carvalho, R.F. Accompanying ions of ammonium sources and nitrate: ammonium ratios in tomato plants. Journal of Plant Nutrition and Soil Science, v. 181, n. 3, p. 382-387, 2018. https://doi. org/10.1002/jpln.201700413.

Chen, H.; Li, Q. P.; Zeng, Y.L.; Deng, F.; Ren, W.J. Effect of different shading materials on grain yield and quality of rice. Scientific Reports, v.9 n.1 p.1-9, 2019. https://doi.org/10.1038/s41598019-46437-9.

Costa, I.J.S; Costa, B.N.S.; Assis, F.A.; Martins, A.D.; Pio, L.A.S.; Pasqual, M. Growth and physiology of jelly palm (Butia capitata) grown under colored shade nets. Acta Scientiarum. Agronomy, v. 40, e35332, 2018. https://doi.org/10.4025/actasciagron. v40i1.35332.

Cruz, J.L.; Pelacani, C.R.; Araújo, W.L Efeito do nitrato e amônio sobre o crescimento e eficiência de utilização do nitrogênio em mandioca. Bragantia, v.65, n.3, p.467-475, 2006. https://doi. org/10.1590/S0006-87052006000300013.

Ferreira, D.F. Sisvar: um programa para análises e ensino de estatística. Revista Symposium, v.6, n.2, p.36-41, 2008. https:// des.ufla.br/ danielff/meusarquivospdf/art63.pdf. 09 Apr. 2021.

Ginegar. ChromatiNet ${ }^{\circledR}$ Raschel. https://www.ginegar.com.br/ agricultura/chromatinet-raschel. 03 Apr. 2021.

Guo, X.R.; Zu, Y.G.; Tang, Z.H. Physiological responses of Catharanthus roseus to different nitrogen forms. Acta Physioogiae Plantarum, v. 34, p. 589-598, 2012. https://doi.org/10.1007/s11738-0110859-9.

Hoagland, D.R.; Arnon, D.I. The water-culture method for growing plants without soil. Berkeley: University of California, 1950. 32p. (California Agricultural Experimental Station. Circular, 347).

Lima, J.C.; Oliveira, U.C.; Santos, A.R.; Souza, A. A.; Souza, G.S. Proporções de amônio e nitrato no crescimento de plantas de Lippia alba (Mill) N. E. Br. cultivadas sob ambientes de luz. Revista de Ciências Agrárias, v.41, n.3, p.655-662, 2018. https://doi. org/10.19084/RCA17240.
Liu, T.; Ren, T.; White, P.J.; Cong, R.; Lu, J. Storage nitrogen coordinates leaf expansion and photosynthetic capacity in winter oilseed rape. Journal of Experimental Botany, v.69, n.12, p.29953007, 2018. https://doi.org/10.1093/jxb/ery134.

Martínez-Andújar, C.; Ghanem, M.E.; Albacete, A.; Pérez-Alfocea, F. Response to nitrate/ammonium nutrition of tomato (Solanum lycopersicum L.) plants overexpressing a prokaryotic $\mathrm{NH}_{4}^{+}$dependente asparagine synthetase. Journal of Plant Physiology, v.170, n.7, p.676-687, 2013. https://doi.org/10.1016/j. jplph.2012.12.011.

Matos, L.S.; Anjos, G.L. dos; Souza, D.S.; Santos, N.S.; Santos, A.R. Desempenho de mudas de manjericão cv. Maria Bonita submetidas a proporções de nitrato e amônio. Enciclopédia Biosfera, v.11 n.22; p.888-895, 2015. https://doi.org/10.18677/ Enciclopedia_Biosfera_2015_125.

Peixoto, C.P, Cruz, T. V, Peixoto, M.F.S.P. Análise quantitativa do crescimento de plantas: Conceitos e Prática. Enciclopédia Biosfera, v.7, n.13, p.51-76, 2011. https://www.conhecer.org.br/ enciclop/2011b/ciencias\%20agrarias/analise\%20quantitativa. pdf. 09 Feb. 2021.

Peixoto, C.P.; Almeida, A.T.; Oliveira, E.R.; Santos, J.M.S.; Peixoto, M.F.S.P.; Poelking, V.G.C. Princípios de fisiologia vegetal: teoria e prática. Rio de Janeiro: Pod Editora, 2020. 256p.

Pinha, G.A.; Alves, I.F.; Romanosque, J.; José Neto, M. O uso de plantas medicinais no município de Três Lagoas. Revista Saúde e Meio Ambiente, v.9, n.3, p.24-33, 2019. https://periodicos.ufms. br/index.php/sameamb/article/view/9144. 09 Feb. 2021.

Silva, J.J.; Santos, A.R.; Sousa, G.S.; Anjos, G.L.; Ferreira, P. M.; Jesus, R.S.; Moreira, G.C. Ambientes de luz e substratos orgânicos na produção e diagnose nutricional de Salvia officinalis L. Brazilian Journal of Development, v.6, n.3, p.15447-15465, 2020. https:// doi.org//10.34117/bjdv6n3-426.

Sousa, V.F.L.; Oliveira, F.A.; Oliveira, F.R.A.; Campos, M.S.; Medeiros, J.F. Efeito do Nitrato e Amônio Sobre o Crescimento da Berinjela. Revista Verde, v.5, n.3, p.80-88, 2010. https://www.gvaa.com.br/ revista/index.php/RVADS/article/view/308/308. 09 Feb. 2021.

Souza, G.S.; Lima, J.C.; Santos, A.R.; Oliveira, U.C.; Bezerra, M.N. Produção de fitomassa de Salvia officinalis $\mathrm{L}$. cultivada sob malhas coloridas e doses de esterco avícola. Revista Verde, v. 12, n. 2, p. 182-186, 2017. https://doi.org/10.18378/rvads.v12i2.4213.

Taiz, L., Zeiger, E., Moller, I.M., Murphy, A. Fisiologia e Desenvolvimento Vegetal. Porto Alegre: Artmed, 2017. 860p.

Teixeira, W.F.; Fagan, E.B.; Silva, J.O.; Silva, P.G.; Silva, F.H.; Sousa, M.C.; Canedo, S. de C. Atividade da enzima nitrato redutase e crescimento de Swietenia macrophylla king sob efeito de sombreamento. Floresta e Ambiente, v. 20, n.1, p.91-98, 2013. https://doi.org/10.4322/floram.2012.068.

Yang, J; Zhu, B; Ni, X; He, Y. Ammonium/nitrate ratio affects the growth and glucosinolates content of pakchoi. Horticultura Brasileira, v.38, p.246-253, 2020. https://doi.org/10.1590/ S0102-053620200302. 